Acta Scientifica Naturalis

Former Annual of Konstantin Preslavsky University - Chemistry, Physics, Biology, Geography Journal homepage: http://www.shu.bg

Received: 30.10 .2016

Accepted: 11.01.2017

\title{
Experimental studies on equilibrium adsorption isosteres and determination of the thermodynamic quantities of polar media on alumina $\mathrm{Al}_{2} \mathrm{O}_{3}$ \\ Albena Yonova \\ “Dede-Agatsch” Str. 17, 9704 Shumen, Bulgaria, e-Mail:a.nova-2000@icon.bg
}

\begin{abstract}
The present work is a review of theoretical and experimental study on the adsorption performance of the adsorbent Alumina $\left(\mathrm{Al}_{2} \mathrm{O}_{3}\right)$ used in the adsorption system. An experimental investigation on the equilibrium adsorption isosteres at low pressure ( $<1 \mathrm{~atm}$ ) of working pairs $\mathrm{Al}_{2} \mathrm{O}_{3} /$ $\mathrm{H}_{2} \mathrm{O}$ and $\mathrm{Al}_{2} \mathrm{O}_{3} / \mathrm{C}_{2} \mathrm{H}_{6} \mathrm{O}_{2}$ is carried out. The isovolume measurement method is adopted in the test setup to directly measure the saturated vapor pressures of working pairs at vapor-liquid equilibrium ( $d G=0$ and $\left.d \mu_{i}=0\right)$. Quantity adsorbed is determined from pressure, volume and temperature using gas law. The isosteric heat of adsorption is calculated from the slope of the plot of $\ln P$ versus $1 / T$ different amounts of adsorbate onto adsorbent as follows: 0,01 vol\% $\mathrm{Al}_{2} \mathrm{O}_{3} / \mathrm{H}_{2} \mathrm{O} ; 0,03$ vol\% $\mathrm{Al}_{2} \mathrm{O}_{3} / \mathrm{H}_{2} \mathrm{O} ; 0,1$ vol\% $\mathrm{Al}_{2} \mathrm{O}_{3} /$ $\mathrm{H}_{2} \mathrm{O} ; 0,01$ vol\% $\mathrm{Al}_{2} \mathrm{O}_{3} / \mathrm{C}_{2} \mathrm{H}_{6} \mathrm{O}_{2} ; 0,03$ vol\% $\mathrm{Al}_{2} \mathrm{O}_{3} / \mathrm{C}_{2} \mathrm{H}_{6} \mathrm{O}_{2} ; 0,1$ vol\% $\mathrm{Al}_{2} \mathrm{O}_{3} / \mathrm{C}_{2} \mathrm{H}_{6} \mathrm{O}_{2}$. This study shows that adsorption working pair $\mathrm{Al}_{2} \mathrm{O}_{3} / \mathrm{C}_{2} \mathrm{H}_{6} \mathrm{O}_{2}$ has better adsorption performances than those of the $\mathrm{Al}_{2} \mathrm{O}_{3} /$ $\mathrm{H}_{2} \mathrm{O}$. Surface acidity is a most important property for both adsorption and catalysis and therefore is examined structure of active sites of alumina surface. Thermodynamic parameters such as isosteric heat of adsorption, isosteric enthalpy and entropy of adsorption are critical design variables in estimating the performance and predicting the mechanism of an adsorption process and are also one of the basic requirements for the characterization and optimization of an adsorption process.
\end{abstract}

Keywords: heterogenous acid-base catalyzer, surface acidity, polar organic solvent, isosteric heat of adsorption, isosteric enthalpy and entropy of adsorption

\section{Introduction}

Studying the thermal conductivity of nanofluids, fluid suspensions of nanometer-sized particles, has grabbed the considerable attention of scientists and engineers in the last decade. The value of liquid thermal conductivity is several orders lower than most of the metals or metal oxides (Table 1).

Table 1. Thermal Conductivity Comparison [1].

34

Corresponding author: a.nova-2000@icon.bg

DOI: 10.1515/asn-2017-0006 


\begin{tabular}{lll}
\hline & \multicolumn{1}{c}{ Materials } & $\begin{array}{c}\text { Thermal Conductivity } \\
(\mathrm{W} / \mathrm{m} \mathrm{K})\end{array}$ \\
\hline Liquids & Carbon nanotube & $200-6000$ \\
& Ethylene glycol & 0.25 \\
& Mineral oil & 0.13 \\
Metal oxide & Water & 0.613 \\
solids & Alumina & 40 \\
& Copper oxide & 70 \\
Metallic solids & Zinc oxide & 60 \\
& Aluminum & 230 \\
& Copper & 398 \\
& Silver & 410 \\
\hline
\end{tabular}

Only four types of generic sorbents have dominated the commercial use of adsorption: activated carbon, zeolites, silica gel, and activated alumina. Estimates of worldwide sales of these sorbents are shown in (Table 2):

Table 2. Worldwide sales of generic sorbents (Humphrey and Keller, 1997) [2].

$\begin{array}{ll}\text { Activated carbon } & \$ 1 \text { billion } \\ \text { Zeolites } & \$ 100 \text { million } \\ \text { Silica gel } & \$ 27 \text { million } \\ \text { Activated alumina } & \$ 26 \text { million }\end{array}$

The efficiency with which electromagnetic radiation is converted into heat is dependent on the dielectric properties of a solvent, i.e., solvents with strong ability to be polarized by the electric field are particularly advantageous for rapid heating. Organic solvents with high microwave adsorbing properties are ethylene glycol, ethanol, dimetylsulfoxide, isopropanol or formic acid. Solvents without a permanent dipole moment like carbon tetrachloride, benzene or dioxane are nearly microwave transparent. Nevertheless, also these solvents can be used for microwave chemistry, as long as other reagents in the reaction mixture are polar. Furthermore, polar additives like ionic liquids can be added to otherwise low-adsorbing media to increase the absorbance. Fast and efficient heating as provided by microwave irradiation bears great potential for large-scale synthesis without suffering thermal gradient effects, and therefore this method became also interesting for the preparation of inorganic nanomaterials. The fast energy transfer directly to the reactants allows an instantaneous decomposition of nanocrystal precursors, creating highly supersaturated solutions [3].

Sorbents with highly polar surfaces (e.g. activated alumina, silica gel, and zeolites) would be desirable for a targeted molecule that has a high dipole moment (and high polarizability). If the targeted molecule has a high quadrupole moment, sorbents with surfaces that have high electric field gradients are needed. Activated alumina is a versatile sorbent that can be tailored for many special applications. New applications continue to be developed, mainly by the aluminum companies. Little is disclosed on the details of their modifications. However, the modifications follow simple general principles of surface chemistry, such as acid-base chemistry. Two methods are used for tailoring: (1) variation of the activation process, and (2) use of dopants. The following are proven applications of various tailored aluminas [2]:

- Removal of $\mathrm{HCl}$ and $\mathrm{HF}$ from gases and liquids;

- Removal of acidic gases $\left(\mathrm{COS}, \mathrm{CO}_{2}, \mathrm{H}_{2} \mathrm{~S}, \mathrm{CS}_{2}\right)$ from hydrocarbons;

35

Corresponding author: a.nova-2000@icon.bg

DOI: 10.1515/asn-2017-0006

C2017 “K.Preslavsky”University of Shumen. All rights reserved 
- Removal of oxygenates and Lewis Bases;

- Removal of polar organic compounds;

- Removal of $\mathrm{As}^{5+}, \mathrm{PO}_{4}{ }^{3-}, \mathrm{Cl}^{-}$, and $\mathrm{F}^{-}$from water;

- Scavenger for organic process liquids;

- Alkalized alumina for $\mathrm{SO}_{2}$ removal.

In study of adsorption thermodynamics, it appears that determination of value of the thermodynamic quantities such as activation energy, activation parameters, Gibb's free energy change, enthalpy, entropy, and isosteric heat of adsorption are required [4].

\section{Theory}

As with ions in solution, the polarity and ionization of surface groups cause their solvation. The presence of a hydration layer on the surface of particles plays a major role in the behavior of colloidal dispersions. Hydrogen bonds in liquid water are responsible for a number of properties of the liquid, and that the presence of ions in the liquid does alter its local structure. The surface groups $\mathrm{M}-\mathrm{OH}, \mathrm{M}-\mathrm{OH}_{2}{ }^{+}$and $\mathrm{M}-\mathrm{O}^{-}$ are polarized and develop very strong interactions with water. They also have a very strong structuring effect on the liquid. Measurements of immersion and adsorption heats, as well as dielectric measurements on oxide surfaces, show that the 2-3 layers of physisorbed water adjacent to the first chemisorbed water layer are immobilized by pairs of hydrogen bonds forming an order similar to that of ice. These bonds are still present at room temperature (Figure 1).

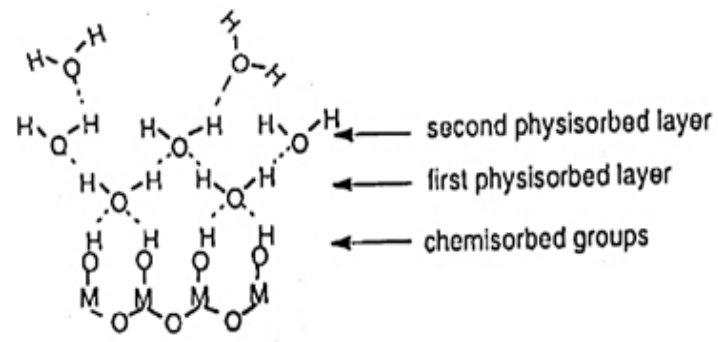

Figure 1. Adsorption of water on an oxide surface [5].

Adsorption of Organic Compounds - Hydrocarbons as well as oxygenated compounds, such as alcohols, are reactants in a large number of metal catalyzed reactions of great industrial importance. The mode and strength of adsorption of organic compounds on catalytic surfaces plays a dominant role, concerning not only the activity but, more important, the selectivity to specific products. In this respect the effect of additives, acting as poison or promoters, is crucial in determining the desired direction of a reaction where organic species participate [6].

Specific and non-specific adsorption - The effect of polarity in enhancing the energy of interaction has been discussed by Kiselev and his associates who distinguish between non-specific adsorption, where only dispersion and repulsive forces are involved and specific adsorption, where coulombic contributions are present in addition. The kinds of interactions resulting from each of the possible adsorbent-adsorbate combinations are summarized in (Table 3):

36

Corresponding author: a.nova-2000@icon.bg

DOI: 10.1515/asn-2017-0006 
Table 3. Specific and non-specific adsorption [7].

\begin{tabular}{cccc}
\hline & \multicolumn{3}{c}{ Class of adsorbent } \\
\cline { 2 - 4 } $\begin{array}{c}\text { Adsorbate } \\
\text { group }\end{array}$ & I & II & III \\
\hline (a) & $n$ & $n$ & $n$ \\
(b) & $n$ & $n+s$ & $n+s$ \\
(c) & $n$ & $n+s$ & $n+s$ \\
(d) & $n$ & $n+s$ & $n+s$ \\
\hline
\end{tabular}

$\mathbf{s}=$ specific adsorption; $\mathbf{n}=$ non-specific adsorption.

(Table 4) contains both inorganic and organic compounds. Organic compounds are similar to inorganic ones when the functional groups responsible for their acid-base properties are the same. Thus, alcohols $(\mathrm{ROH})$ are similar to water $(\mathrm{HOH})$ in both their Brønsted acidity (ability to donate a proton from oxygen) and Brønsted basicity (ability to accept a proton on oxygen).

Table 4. Properties of some Brønsted Acids as possible adsorbates for $\mathrm{Al}_{2} \mathrm{O}_{3}$ (adsorbent class II) $[8,9,10]$.

\begin{tabular}{|c|c|c|c|c|}
\hline $\begin{array}{l}\text { Brønsted Acid } \\
\text { (Formula) }\end{array}$ & $\begin{array}{c}\text { Thermal } \\
\text { Conductivity } \\
\text { in } \mathrm{W} / \mathrm{mK} \\
\left(25^{\circ} \mathrm{C}\right)\end{array}$ & $\begin{array}{l}\text { Dielectric } \\
\text { constant, } \varepsilon\end{array}$ & $\begin{array}{c}\text { Dissociation } \\
\text { constant } \\
\text { pKa }\left(25^{\circ} \mathrm{C}\right)\end{array}$ & Conjugate base \\
\hline \multicolumn{5}{|c|}{$\begin{array}{l}\text { I.Adsorbate group D: Water - high polar }(\varepsilon>40) \text { and Alcohols - middle polar }(\varepsilon=10 \div 40) \text { and high } \\
\text { polar }(\varepsilon>40) \text { - nonspecific and specific adsorption }\end{array}$} \\
\hline Water HOH & 0,6062 & 80,1 & 14 & $\mathrm{HO}^{-}$ \\
\hline $\begin{array}{l}\text { Ethylene glycol } \\
\mathbf{H O}-\mathbf{C H}_{2}-\mathbf{C H}_{2}-\mathbf{O H}\end{array}$ & 0,254 & 41,4 & 14,22 & $\left(\mathrm{CH}_{2} \mathrm{O}^{-}\right)_{2}$ \\
\hline $\begin{array}{l}\text { Propylene glycol } \\
\mathbf{H O}-\mathbf{C H}_{2}-\mathbf{C H}_{2}-\mathbf{C H}_{2}-\mathbf{O H}\end{array}$ & 0,200 & 27,5 & 14,8 & $\left(\mathrm{CH}_{2}\right)_{3} \mathrm{O}_{2}^{-}$ \\
\hline Methanol $\mathbf{C H}_{3} \mathbf{O H}$ & 0,202 & 33 & 15,54 & $\mathrm{CH}_{3} \mathrm{O}^{-}$ \\
\hline $\begin{array}{l}\text { Isopropyl alcohol } \\
\left(\mathbf{C H}_{3}\right)_{2} \mathbf{C H O H}\end{array}$ & 0,135 & 20,18 & $\approx 17$ & $\left(\mathrm{CH}_{3}\right)_{2} \mathrm{CHO}^{-}$ \\
\hline $\begin{array}{l}\text { tert-Butyl alcohol } \\
\left(\mathbf{C H}_{3}\right)_{3} \mathbf{C O H} \\
\end{array}$ & 0,112 & 12,47 & $\approx 18$ & $\left(\mathrm{CH}_{3}\right)_{3} \mathrm{CO}^{-}$ \\
\hline \multicolumn{5}{|c|}{ II. Adsorbate group A: Saturated hydrocarbons - non polar $(\varepsilon<4)$ - nonspecific adsorption } \\
\hline n-Hexane $\mathbf{C}_{6} \mathbf{H}_{14}$ & 0,1167 & 1,8865 & $\approx 18$ & $\mathrm{CH}_{2}=\mathrm{CH}\left(\mathrm{CH}_{2}\right)_{3} \mathrm{CH}_{3}^{-}$ \\
\hline
\end{tabular}

Studies have shown that the more stable a carbocation is, the faster it is formed. These studies demonstrate that alkyl groups directly attached to the positively charged carbon stabilize a carbocation. Thus, the observed order of carbocation stability is:

37

Corresponding author: a.nova-2000@icon.bg DOI: $10.1515 /$ asn-2017-0006 


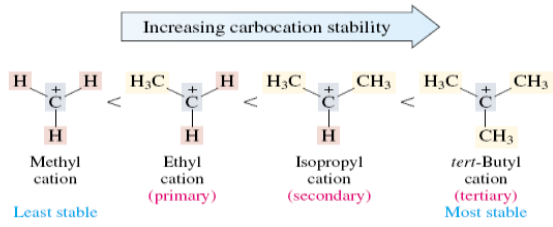

Figure 2. Increasing carbocation stability [8].

The important thermodynamic variable to describe the heat effects during the adsorption process is the isosteric heat of adsorption. The isosteric heat of adsorption $\mathrm{Q}_{\mathrm{a}}$ is determined graphically from angular coefficient of straight line (Figure 3).

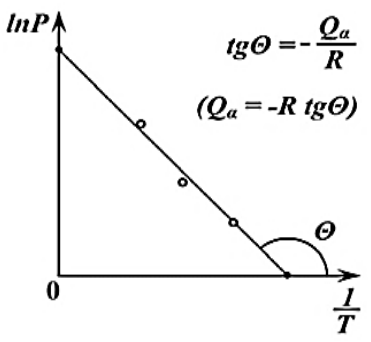

Figure 3. Isostere in $\ln \mathrm{P}=\mathrm{f}(1 / \mathrm{T})$ coordinates [11].

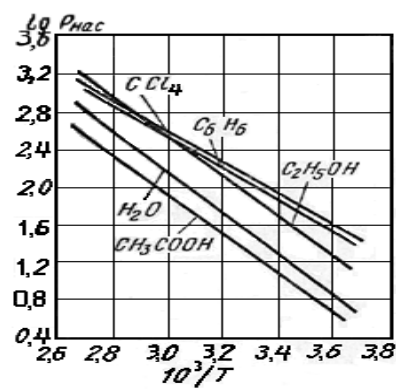

Figure 4. Isosteres of liquids [12].

If the slope of all isosteres is constant, that means, in examined interval the heat of adsorption is not depending on degree of filling of surface [13].

New adsorbents very interesting in adsorption and chromatography are porous polymers. Depending on content-rate of binding element can prepare porous polymers with specific surface area $10 \div 600 \mathrm{~m}^{2} / \mathrm{g}$. That sort of adsorbents possess specific character, activated $\pi$-bonds on their surfaces. According to Kiselev's classification, these adsorbents are class III, i.e. carry on surface negative charge. (Figure 5) shows dependence of heat of adsorption of substances on their electron polarization.

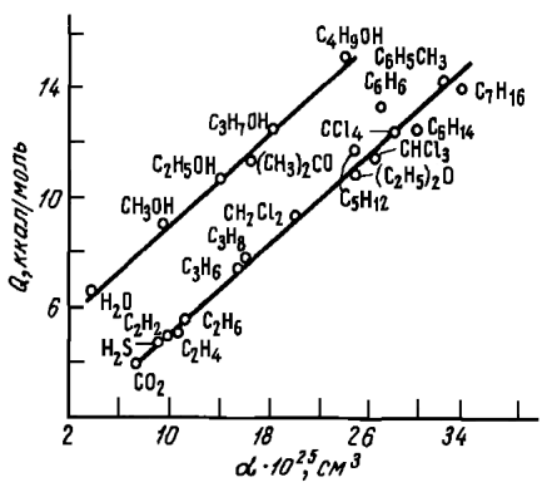

Figure 5. Dependence of heat of adsorption of substances from group A, B, D on electron polarization of their molecules on porous polymer (class III) "Хромосорб-102" [14]. 
Activated alumina has higher ultimate capacities for water vapor than zeolites do. When high removals of water vapor (to very low dew points) are required, zeolites are used because their water capacities at very low concentrations are higher, as shown in (Figure 6).

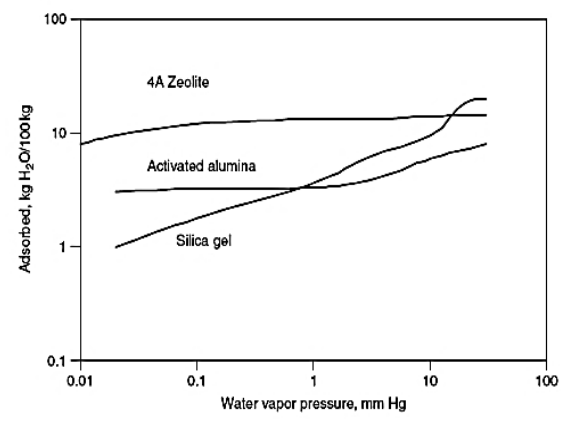

Figure 6. Comparison of water adsorption on various sorbents [2].

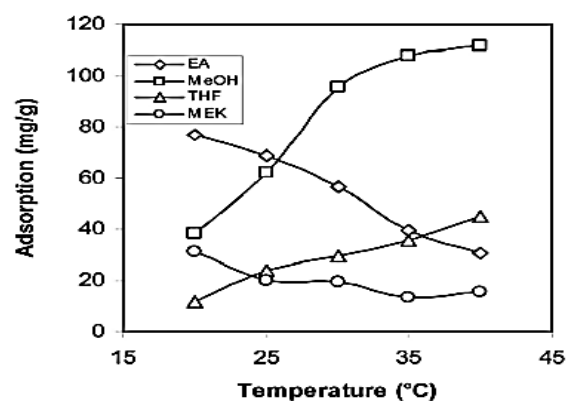

Figure 7. Adsorption isotherms of different organic solvents such as ethyl acetate (EA), methanol $(\mathrm{MeOH})$, terahydrofuran (THF) and methylethyl ketone (MEK) on $\gamma$-alumina particles $(0,1 \mathrm{~g})$ at various temperatures [15].

Pore structure and surface chemistry of the activated alumina can be manipulated and controlled. The acidity of the surface can be increased by treatment with acid, such as $\mathrm{HCl}$ and $\mathrm{HF}$ (Figure 8.1). Sorption volume increases by higher electrolyte content (Figure 8.2).

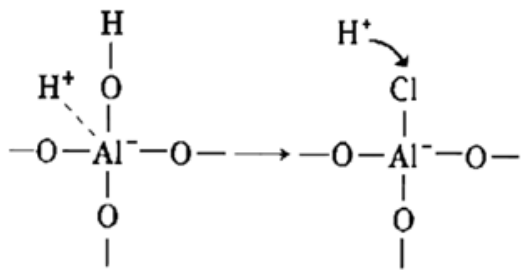

Figure 8.1. Figure 8.1. Alumina surface by the acid treatment [16]

39 


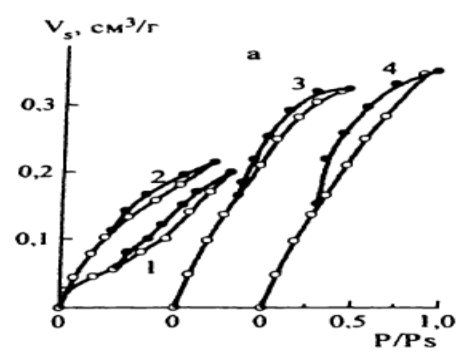

Figure 8.2. Isoterms of adsorption of water vapor on $\mathrm{Al}(\mathrm{OH})_{3}$, manipulated with supersound (6 min) and vibration (6 min) in presence of electrolyte $\mathrm{AlCl}_{3} ; 1-\mathrm{Al}(\mathrm{OH})_{3}, 2,3,4$ - isoterms of adsorption on $\mathrm{Al}(\mathrm{OH})_{3}$, manipulated with supersound and vibration in presence of $2,4,6$ mass $\%$ electrolyte $\mathrm{AlCl}_{3}$ respectively [17].

The investigations were carried out by constant temperatures 60 and $75{ }^{\circ} \mathrm{C}$ for pure isopropanol and nannofluids with mass concentration of nanoparticles $\mathrm{Al}_{2} \mathrm{O}_{3} 0,05$ and 0,1 mass.\%. The experimental data for influence of nanoparticles on heat transfer coefficient is shown on (Figure 9). The analysis of given boiling curves show, that presence of nanoparticles in liquid can increase heat transfer coefficient at boiling with $10 \div 26 \%$. This effect is observed only by small densities of heat flux and decrease with increasing of temperatures and concentrations of nanoparticles. By high densities of heat flux the presence of nanoparticles in base liquid lead to decreasing intensity of heat exchange [18].
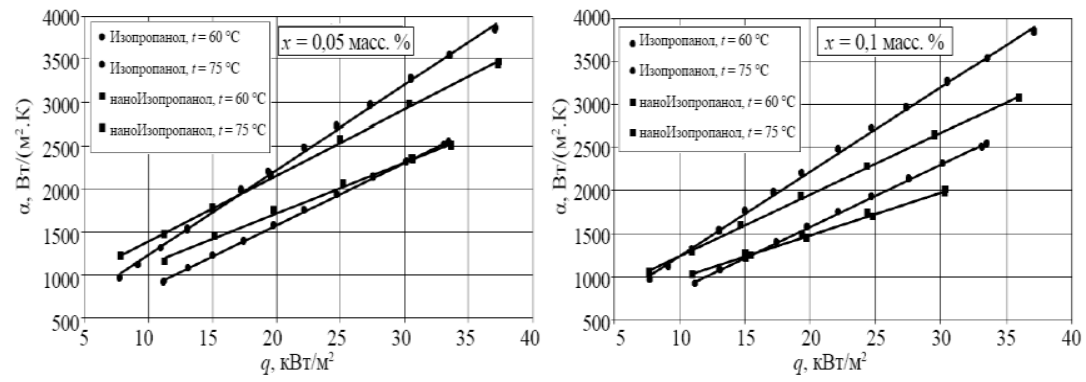

Figure 9. Dependence of heat transfer coefficient $\alpha, \mathrm{W} /\left(\mathrm{m}^{2} . \mathrm{K}\right)$ on density of heat flux $\mathrm{q}, \mathrm{kW} / \mathrm{m}^{2}[18]$.

\section{Materials and methods}

$\mathrm{Al}_{2} \mathrm{O}_{3}$ is acid component and owns weak acidity. Activated alumina is crystalline and is also widely used as a desiccant. The exterior surfaces of $\gamma-\mathrm{Al}_{2} \mathrm{O}_{3}$ are rich in $\mathrm{OH}$ groups. Oxygen vacancies (defects) are easily formed on its surfaces, thus alumina has both Lewis acid sites (i.e. sites that can accept electrons, these are the $\mathrm{Al}^{3+}$ sites on the surfaces) and Brønsted acid sites (i.e., - $\mathrm{OH}$ groups that can donate protons) (Figure 10). The surface chemistry, as well as the pore structure of activated alumina, can be modified, for example, by treatment with acid ( $\mathrm{HCl}$ or $\mathrm{HF}$ ) or alkaline (to alter the acidity) and controlled thermal treatment (to tailor the pore structure) [2].

40

Corresponding author: a.nova-2000@icon.bg DOI: $10.1515 /$ asn-2017-0006 


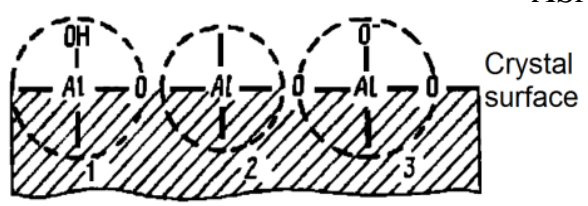

Figure 10. Structure of active sites of alumina surface $\left(\gamma-\mathrm{Al}_{2} \mathrm{O}_{3}\right)$. 1-Brønsted acid sites; 2-Lewis acid site; 3- Base site [19].

As seen in (Table 5), $\gamma$-alumina has a good surface area for adsorption and a good macropore volume and mean pore size for fast transport of molecules from the surrounding to the interior.

Table 5. Typical characteristics of $\gamma$-alumina [20].

\begin{tabular}{ll}
\hline True density & $2.9-3.3 \mathrm{~g} / \mathrm{cc}$ \\
Particle density & $0.65-1.0 \mathrm{~g} / \mathrm{cc}$ \\
Total porosity & $0.7-0.77$ \\
Macropore porosity & $0.15-0.35$ \\
Micropore porosity & $0.4-0.5$ \\
Macropore volume & $0.4-0.55 \mathrm{cc} / \mathrm{g}$ \\
Micropore volume & $0.5-0.6 \mathrm{cc} / \mathrm{g}$ \\
Specific surface area & $200-300 \mathrm{~m}^{2 / g}$ \\
Mean macropore radius & $100-300 \mathrm{~nm}$ \\
Mean micropore radius & $1.8-3 \mathrm{~nm}$ \\
\hline
\end{tabular}

Ethylene glycol $\left(\mathrm{C}_{2} \mathrm{H}_{6} \mathrm{O}_{2}\right)$ is an organic polar solvent that can be used over a wide range of temperatures. Ethylene glycol is popular in snow-melting systems because of their moderate cost, high specific heat, and low viscosity; ease of corrosion control is another advantage. Automotive radiator antifreezes are mostly based on ethylene glycol. Owing to the strong hydrogen-bonding properties of this double alcohol, this substance is completely miscible with water and many organic liquids, and contributes only a very small vapor pressure of its own. Besides lowering the freezing point, antifreeze also raises the boiling point, increasing the operating range of the cooling system.

Heat is not a state function and the value of the heat of adsorption depends on both the experimental conditions and the employed method of measurement [21]. Method of measurement is heat of adsorption from Indirect Non-Calorimetric Method.

\section{Results and discussion}

Table 6. Observations on the equilibrium adsorption of $\mathrm{Al}_{2} \mathrm{O}_{3}$ suspensions' test samples at low pressure $(<1 \mathrm{~atm})$.

\begin{tabular}{|c|l|c|c|c|c|}
\hline $\begin{array}{c}\text { Test } \\
\text { sample } \\
\mathbf{N o}\end{array}$ & \multicolumn{1}{|c|}{ Suspension } & $\begin{array}{c}\text { Surface concentration of } \\
\text { adsorbent }\left(\mathbf{A l}_{\mathbf{2}} \mathbf{O}_{\mathbf{3}}\right), \mathbf{~ m}^{\mathbf{2}} / \mathbf{m o l}\end{array}$ & $\begin{array}{c}\mathbf{Q}_{\text {ads, }}, \\
\mathbf{J} / \mathbf{k g}\end{array}$ & $\begin{array}{c}\Delta \mathbf{H}_{\text {ads, }}, \\
\mathbf{J} / \mathbf{k g}\end{array}$ & $\begin{array}{c}\Delta \mathbf{S}_{\text {ads, }} \\
\mathbf{J} /(\mathbf{k g . K})\end{array}$ \\
\hline 1.1 & $0,1 \mathrm{vol} \% \mathrm{Al}_{2} \mathrm{O}_{3} / \mathrm{C}_{2} \mathrm{H}_{6} \mathrm{O}_{2}$ & 39,3743 & 29,56 & $-29,56$ & $-4,52$ \\
\hline 1.2 & $0,03 \mathrm{vol} \% \mathrm{Al}_{2} \mathrm{O}_{3} / \mathrm{C}_{2} \mathrm{H}_{6} \mathrm{O}_{2}$ & 10,8619 & 30,21 & $-30,21$ & $-4,54$ \\
\hline 1.3 & $0,01 \mathrm{vol} \% \mathrm{Al}_{2} \mathrm{O}_{3} / \mathrm{C}_{2} \mathrm{H}_{6} \mathrm{O}_{2}$ & 5,4309 & 33,46 & $-33,46$ & $-4,68$ \\
\hline 2.1 & $0,1 \mathrm{vol} \% \mathrm{Al}_{2} \mathrm{O}_{3} / \mathrm{H}_{2} \mathrm{O}$ & 11,4250 & 35,69 & $-35,69$ & $-5,73$ \\
\hline
\end{tabular}

41

Corresponding author: a.nova-2000@icon.bg DOI: 10.1515/asn-2017-0006 


\begin{tabular}{|l|l|l|l|l|l|}
\hline 2.2 & $0,03 \mathrm{vol} \% \mathrm{Al}_{2} \mathrm{O}_{3} / \mathrm{H}_{2} \mathrm{O}$ & 3,1517 & 30,80 & $-30,80$ & $-5,58$ \\
\hline 2.3 & $0,01 \mathrm{vol} \% \mathrm{Al}_{2} \mathrm{O}_{3} / \mathrm{H}_{2} \mathrm{O}$ & 1,5759 & 34,14 & $-34,14$ & $-5,68$ \\
\hline
\end{tabular}

The natural logarithm of $\mathrm{p}$ was plotted for a given surface concentration of adsorbent $\mathrm{Al}_{2} \mathrm{O}_{3}$, against the inverse of the temperature in Kelvin in (Figure 11(a)) and (Figure 11(b)). The pressure in each case was measured. This gives the isosteric plot as defined by Clausius-Clapeyron equation.

$$
\ln p=\frac{\Delta H_{a d s}}{R \cdot T}-\frac{\Delta S_{a d s}}{R}
$$

From these plots is found:

- the isosteric enthalpy of adsorption $\Delta \mathrm{H}_{\mathrm{ads}}$ from the slope and

- the isosteric entropy of adsorption $\Delta S_{\text {ads }}$ from the intercept.

Heat of adsorption and enthalpy of adsorption [22]:

$$
\mathrm{Q}_{\mathrm{ads}}=-\Delta \mathrm{H}_{\mathrm{ads}}
$$

The adsorption of gases and vapors on solids is always an exothermic process.

$$
\mathrm{Q}_{\mathrm{ads}}>0,(\Delta \mathrm{H}<0)
$$

\begin{tabular}{|c|c|c|c|}
\hline 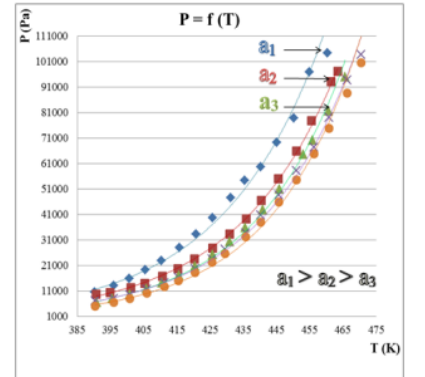 & 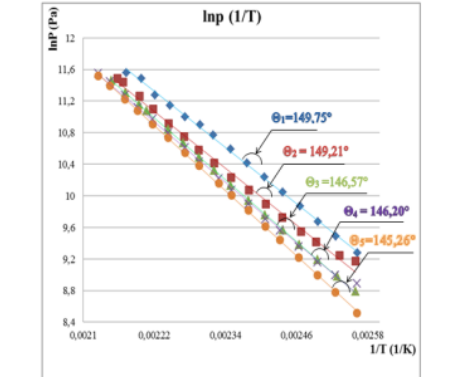 & 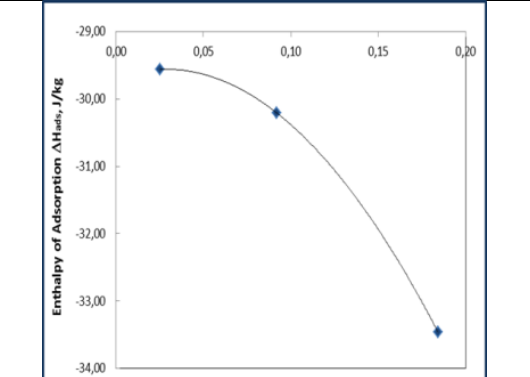 & 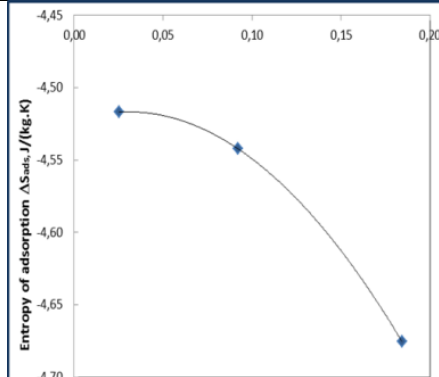 \\
\hline Figure 11. (a) & Figure 12. (a) & Figure 13. (a) & 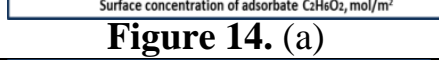 \\
\hline 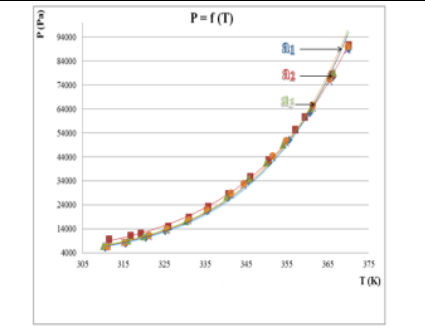 & 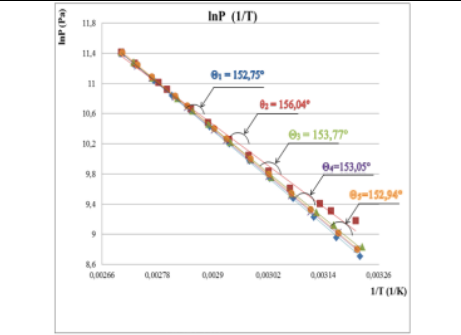 & 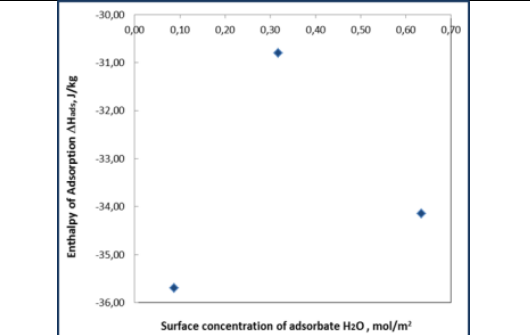 & 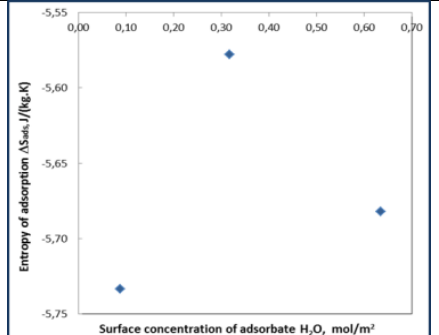 \\
\hline Figure 11. (b) & Figure 12. (b) & Figure 13. (b) & Figure 14. (b) \\
\hline $\begin{array}{l}\text { Figure 11. Equilibrium } \\
\text { adsorption isosteres } p= \\
\text { f(T) by } a=\text { const of the } \\
\text { composite adsorbent: } \\
\text { (a) } \mathrm{Al}_{2} \mathrm{O}_{3} / \mathrm{C}_{2} \mathrm{H}_{6} \mathrm{O}_{2} \text { and } \\
\text { (b) } \mathrm{Al}_{2} \mathrm{O}_{3} / \mathrm{H}_{2} \mathrm{O} \text {. }\end{array}$ & $\begin{array}{l}\text { Figure 12. Equilibrium } \\
\text { adsorption } \\
\text { lnP=f(1/T) by a=const of the } \\
\text { composite adsorbent: } \\
\text { (a) } \mathrm{Al}_{2} \mathrm{O}_{3} / \mathrm{C}_{2} \mathrm{H}_{6} \mathrm{O}_{2} \text { and } \\
\text { (b) } \mathrm{Al}_{2} \mathrm{O}_{3} / \mathrm{H}_{2} \mathrm{O} \text {. }\end{array}$ & $\begin{array}{l}\text { Figure 13. Isosteric enthalpy of } \\
\text { adsorption as a function of } \\
\text { surface concentration } \\
\text { adsorbate: } \\
\text { (a) } \mathrm{C}_{2} \mathrm{H}_{6} \mathrm{O}_{2} \text { on adsorbent } \mathrm{Al}_{2} \mathrm{O}_{3} \\
\text { and } \\
\text { (b) } \mathrm{H}_{2} \mathrm{O} \text { on adsorbent } \mathrm{Al}_{2} \mathrm{O}_{3} \text {. }\end{array}$ & 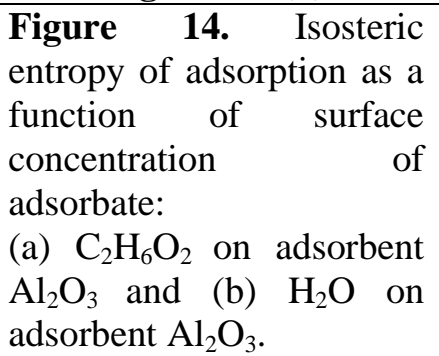 \\
\hline
\end{tabular}

42

Corresponding author: a.nova-2000@icon.bg DOI: 10.1515/asn-2017-0006 


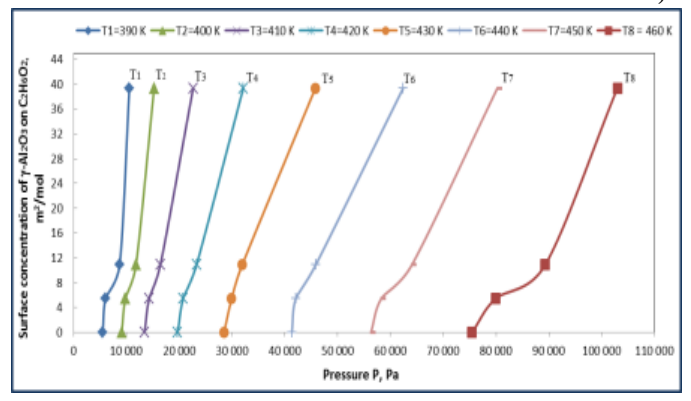

Figure 15. Saturation of phase boundary of test sample №1.1, №1.2 and №1.3 (according Table 6).

Equilibrium adsorption isosteres $\mathrm{p}=\mathrm{f}(\mathrm{T})$ correspond to increasing quantity of adsorption $\mathrm{a}_{1}>\mathrm{a}_{2}>\mathrm{a}_{3}$ (Figure 11). The straight lines mean that the enthalpy of adsorption can be regarded as a negligible function of temperature. The results for the isosteric enthalpy and entropy of adsorption are plotted in (Figure 13(a), Figure 13(b), Figure 14(a) and Figure 14(b)). The values in both plots are changing with surface concentration of adsorbate (a) $\mathrm{C}_{2} \mathrm{H}_{6} \mathrm{O}_{2}$ (b) Distilled water $\mathrm{H}_{2} \mathrm{O}$. In (Figure 13(a) and Figure 14(a)) both decrease with increasing surface concentration of adsorbate $\mathrm{C}_{2} \mathrm{H}_{6} \mathrm{O}_{2}$. The isosteric enthalpy varies between $-29,56$ and $-33,46 \mathrm{~J} / \mathrm{kg}$. The isosteric entropy varies between $-4,52$ and $-4,68 \mathrm{~J} / \mathrm{kg} . \mathrm{K})$. The effect of the concentration is much more noticeable on the value of the enthalpy $\Delta \mathrm{H}_{\mathrm{ads}}, 390 \%$ of change, than on the entropy $\Delta \mathrm{S}_{\mathrm{ads}}, 16 \%$ of change, indicating large enthalpic effects on the surface. The conclusion is that the system has characteristic properties for physisorption.

\section{Conclusions}

A set of specific adsorption in the system solid-solvent organic and nonorganic molecules is explained in the work as a result of theoretical and experimental material. Key conclusions can be summarized as follows:

- The higher adsorption of $\mathrm{C}_{2} \mathrm{H}_{6} \mathrm{O}_{2}$ on the alumina surface is accompanied by the formation of hydrogen bond as both alumina surface and $\left(\mathrm{HO}-\mathrm{CH}_{2}-\mathrm{CH}_{2}-\mathrm{OH}\right)$ contain hydroxyl groups and $\mathrm{C}_{2} \mathrm{H}_{6} \mathrm{O}_{2}$ has weaker acid properties in comparison with $\mathrm{H}_{2} \mathrm{O}$.

- The higher adsorption of $\mathrm{C}_{2} \mathrm{H}_{6} \mathrm{O}_{2}$ is due to higher surface concentration of $\mathrm{Al}_{2} \mathrm{O}_{3} / \mathrm{C}_{2} \mathrm{H}_{6} \mathrm{O}_{2}$ in comparison with $\mathrm{Al}_{2} \mathrm{O}_{3} / \mathrm{H}_{2} \mathrm{O}$ (Table 6).

- From Figures 11(b), 12(b), 13(b) and 14(b) can see negligible change of isosteric heat of adsorption, enthalpy and entropy for suspension of polar adsorbate $\mathrm{H}_{2} \mathrm{O}$ on $\mathrm{Al}_{2} \mathrm{O}_{3}$, i.e. negligible adsorption and in this instance alumina surface can treat with acid, such as $\mathrm{AlCl}_{3}$ (Figure 8) or can replace with other adsorbent like zeolite (Figure 6) .

- The enthalpy values of $\Delta \mathrm{H}_{\mathrm{ads}}<50 \mathrm{~kJ} \mathrm{~mol}^{-1}$ for $\mathrm{Al}_{2} \mathrm{O}_{3} / \mathrm{C}_{2} \mathrm{H}_{6} \mathrm{O}_{2}$ and $\mathrm{Al}_{2} \mathrm{O}_{3} / \mathrm{H}_{2} \mathrm{O}$ confirm that physisorption was involved in the adsorption process.

- Negative $\Delta \mathrm{H}_{\text {ads }}$ and $\Delta \mathrm{S}_{\text {ads }}$ suggest that the adsorption of gases and vapors $\mathrm{H}_{2} \mathrm{O}$ and $\mathrm{C}_{2} \mathrm{H}_{6} \mathrm{O}_{2}$ onto solid $\mathrm{Al}_{2} \mathrm{O}_{3}$ was exothermic $\left(\mathrm{Q}_{\mathrm{ads}}>0\right)$ and nonspontaneous $(\Delta \mathrm{S}<0)$.

- Type IV isotherm, multilayer adsorption for suspensions high porosity $\mathrm{Al}_{2} \mathrm{O}_{3} / \mathrm{H}_{2} \mathrm{O}$ and $\mathrm{Al}_{2} \mathrm{O}_{3} /$ $\mathrm{C}_{2} \mathrm{H}_{6} \mathrm{O}_{2}$.

43

Corresponding author: a.nova-2000@icon.bg

DOI: 10.1515/asn-2017-0006

C2017 “K.Preslavsky”University of Shumen. All rights reserved 
- The heat of adsorption increase with increasing of alkyl groups in primary, secondary and tertiary alcohols (Figure 5) from studied literature.

- Adsorption and heat transfer coefficient at boiling decrease with increasing of temperatures, densities of heat flux and concentrations of nanoparticles (Figure 9) from studied article.

\section{References}

[1] Sattler, K., D., Handbook of Nanophysics - Nanoparticles and Quantum Dots, CRC Press, 2011, 718.

[2] Yang, R. T., Adsorbents: Fundamentals and applications, Wiley-Interscience, 2003, 410.

[3] Niederberger, M.; Pinna, N., Metal Oxide Nanoparticles in Organic Solvents. Synthesis, Formation, Assembly and Application, Springer Verlag, 2009, 216.

[4] Saha, P.; Chowdhury, S., Insight Into Adsorption Thermodynamics, Thermodynamics, 2011, $349 \div 364$.

[5] Jolivet, J.; Henry, M.; Livage, J.; Bescher, E., Metal Oxide Chemistry and Synthesis. From Solution to Solid State, John Wiley \& Sons, LTD, 2000, 3, 321.

[6] Vayenas, C. G.; Pliangos, C.; Bebelis, S.; Brosda, S.; Tsiplakides, D., Electrochemical Activation of Catalysis. Promotion, Electrochemical Promotion, and Metal-Suport Interactions, Kluwer academic publishers, 2002, 574.

[7] Gregg, S., J.; Sing, K. S. W., Adsorption, Surface Area and Porosity, Academic press inc. London Ltd., 1982, 2, 303.

[8] Carey, F. A., Organic Chemistry, 2000, 126 $\div 166$.

[9] Dean, J. A., Lange's Handbook of chemistry, McGRAW-HILL, INC, 1999, 15, 1561.

[10] Lide, D. R., CRC Handbook of Chemistry and Physics, CRC Press LLC, 2005, 85, 2660.

[11] Мачкова, М.; Гиргинов, А., Колоидна химия, Химикотехнологичен и металургичен университет, 2013, 127.

[12] Еремин, Е., Н., Основы химической термодинамики, Москва Высшая школа, 1974, 341.

[13] Карнаухов, А. П., Адсорбция. Текстура дисперсных и пористых материалов, Новосибирск Наука Сибирское предприятие РАН, 1999, 470.

[14] Дубинин, М. М., Основные проблемы теории физической адсорбции, Издательство Наука, Москва, 1970, 476.

[15] Karim, M., R.; Rahman, M., A.; Miah, M., A., J.; Ahmad, H.; Yanagisawa, M.; Ito, M., Synthesis of $\gamma$-Alumina Particles and Surface Characterization, The Open Colloid Science Journal, 2011, 4, 32-36.

[16] Сеттерфилд, Ч., Практический курс гетерогенного катализа, Москва Мир, 1984, 520.

[17] Комаров, В. С., Синтез и регулирование пористой структоры адсорбентов, Белорусское издателькое Товарищество Хата, 2003, 274.

[18] Железный, В. П.; Семенюк, Ю. В.; Никулин, А. Г.; Лукьянов, Н. Н., Методические особености экспериментального изучения процессов кипения нанофлюидов в свободном обеме, Одесская национальная академия пищевых технологий, вестник МАХ, 2014, 3, 4-9.

44

Corresponding author: a.nova-2000@icon.bg DOI: 10.1515/asn-2017-0006 
[19] Краснов, К. С.; Воробьев, Н. К.; Годнев И. Н. и др., Физическая химия. В 2 кн. Кн.2. Электрохимия. Химическая кинетика и катализ: Учеб. для вузов, Москва Высшая школа, 1995, 2, 319.

[20] Thomas, J., M.; Thomas, W., J., Principles and practice of heterogeneous catalysis, VCH Verlagsgesellschaft mbH, 1997, 669.

[21] Ruthven, D. M., Principles of adsorption and adsorption processes, A Wiley - Interscience publication John Wiley \& Sons, Canada, 1984, 433.

[22] Stolen, S.; Grande, T.; Allan, N., L., Chemical Thermodynamics of Materials, John Wiley \& Sons, Ltd, 2004, 396. 